\title{
Metaphysics without Pre-Critical Monism: Hegel on Lower-Level Natural Kinds and the Structure of Reality
}

\author{
by James Kreines
}

Bulletin of the Hegel Society of Great Britain 57/58 2008 pp. 48-70.

\section{Hegel and Metaphysics}

Recent debates about Hegel's theoretical philosophy are marked by a surprising lack of agreement, extending all the way down to the most basic question: what is Hegel talking about ${ }^{1} \mathrm{On}$ the one hand, proponents of 'metaphysical' interpretations generally read

\footnotetext{
${ }^{1}$ Abbreviations:

A/B: Kant, Immanuel (1998), Critique of Pure Reason. P. Guyer and A. Wood trs., Cambridge: Cambridge University Press.

Ak: Aside from references to the Critique of Pure Reason, all other references to Kant's writings are given by volume and page number of the Akademie edition of Kant's Gesammelte Schriften (Berlin: de Gruyter, 1902-).

EL: Hegel, G.W.F (1991), Encyclopaedia Logic. T.F Geraets, H.S Harris, and W.A Suchting trs., Hackett Publishing Co. Indiana. Encyclopedia cited by $\int$ number, with 'An' indicating Anmerkung and 'Zu' indicating the Zusatz. All other references to Hegel's writings are given by volume and page number of Hegel, G.W.F (1970-1), Werke in zwanzig Bände. E. Moldernhauer und K. Michel eds., Frankfurt: Suhrkamp.

Ethics: Spinoza, B. (1994), A Spinoza Reader. E. Curley ed., and tr., Princeton: Princeton University Press.

Phän: Hegel, G.W.F (1977), Phenomenology of Spirit A..V. Miller tr., Oxford: Oxford University Press.

PG: Hegel, G.W.F (1971), Hegel's Philosophy of Mind. W. Wallace and A. V. Miller trs., New York: Oxford University Press.

PN: Hegel, G.W.F (1970), Hegel's Philosophy of Nature.W. Wallace and A. V. Miller trs., New York: Oxford University Press.

PP: Hegel, G.W.F (1986), The Philosophical Propaedentic. M. George \& A. Vincent, eds., A. V. Miller, tr. Oxford, Blackwell.

VGP: Hegel, G.W.F (1995), Lectures on the History of Philosophy. 3 vols. E. S. Haldane and F. H. Simson trs., Lincoln: University of Nebraska Press.

VPA: Hegel, G.W.F (1975), Aesthetics: Lectures on Fine Art. 3 vols. T.M.Knox tr., Oxford: Clarendon Press.

WL: Hegel, G.W.F (1969), Hegel's Science of Logic. A.V. Miller tr., London: George Allen \& Unwin.
} 


\section{Metaphysics without Pre-Critical Monism: Hegel on Lower-Level Natural Kinds and the Structure of Reality}

Hegel as aiming to articulate the overall structure or organisation of reality itself, and the nature of a highest or most fundamental being. Particularly influential is the idea that Hegel is reviving and modifying a form of Spinoza's metaphysical monism, according to which the organised whole of everything is the highest being, providing a ground or reason for everything real. ${ }^{2}$ On the other hand, proponents of 'non-metaphysical' interpretations argue Hegel's topic is something else entirely. The idea is that Hegel agrees with Kant in finding pre-critical forms of metaphysics to be uncritical or dogmatic. And the topic of Hegel's positive project is supposed to be not the nature of reality itself, nor any most fundamental being, but rather 'forms of thought' akin to Kant's categories and the objectivity, legitimacy, or normative authority of those forms of thought. ${ }^{3}$

This is of course only a rough sketch of the most basic recent debate, about which there is more to say than can fit in this paper. My focus here is on what Hegel has to say about nature and natural kinds, in 'Observing Reason' from the Phenomenology, and also in similar material from the Logic and Encyclopedia. I intend to argue that this material suggests a surprising way of stepping beyond the fundamental debate sketched above. There can of course be no question of elaborating and defending here a complete interpretation of Hegel's entire theoretical philosophy. I will have to restrict myself to arguing for the unlikely conclusion that there is an approach that can combine and integrate the strongest points made by both sides in the most basic debate shaping recent Hegel interpretation.

In defending such a conclusion, it is necessary to avoid resting any weight on mere invocation of Hegel's terminology. At the end of the day, the basic point must not be that Hegel's view is dialectical and thus both cancels and preserves metaphysics. For this alone would not explain anything. What needs explaining is how there could be any single coherent position that in any philosophical sense both cancels and preserves metaphysics.

\footnotetext{
${ }^{2}$ Some hold that Hegel sees this ground of everything as a mind or spirit ['Geist'] or 'subject' which is somehow freely self-creating (e.g. Taylor 1975: 87ff.). Others understand Hegel's modification of Spinoza in this way: everything real is determined by a fundamental organising principle of the whole, which interpreters often call a basic 'structure.' This is supposed to be what Hegel himself refers to as 'the idea.' It is not itself a mind; it is an organising principle which governs both natural and mental phenomena, although it is more completely realised in the latter. See Horstmann on 'primary structure' (Horstmann 1991: 177-82) and the similar formulation at Horstmann 1998/2004: Part 4; also Beiser on Hegel's modification of Spinoza's monism (Beiser 1993 and 2005).

${ }^{3}$ Hartmann: 'Hegel advocates a 'modest ... hermeneutic of categories,' or 'a non-metaphysical philosophy devoid of existence claims and innocent of a reductionism opting for certain existences to the determinant of others' (Hartmann 1972: 124 and 110). Later non-metaphysical interpreters differ in many respects but also read Hegel's project as focused not on metaphysical issues but on our concepts and their legitimacy. For example, Pippin: 'Most of Hegel's significant revisions of Kant involve his transformation of Kant's theory of concepts, his reinterpretation of Kant's account of the objectivity of concepts, and his different treatment of the notion of subjectivity relevant to an idealist version of such issues.' (Pippin 1989:7). Hegel follows what Brandom describes as a Kantian 'shift in attention from ontological questions ... to deontological ones' (Brandom 1999: 65).
} 
To do better, I first need to define some terms, not in a manner aimed to mirror Hegel's own usage, but rather in a manner aimed at making recent debates and my claims in response to them as clear as possible. First, by 'metaphysics' I mean any claim or theory concerning reality itself, and especially any claim or theory about a general nature of reality, general features or structure of reality, or about relations of dependence and independence among real things.

Second, I want to single out a specific kind of metaphysics. By 'metaphysical rationalism' I mean any view combining these two features: a commitment to a principle of sufficient reason, requiring that everything real must depend on some complete underlying ground or reason, so that there must be a complete explanation for everything; and also, an inference to the conclusion that there must ultimately be some one fundamental being that grounds or provides the ultimate or complete reason for absolutely everything. ${ }^{4}$

Metaphysical rationalism is of great importance in Kant's Critique of Pure Reason. Kant argues that the faculty of reason always demands that we seek underlying conditions, and ultimately that we seek a complete series of conditions, or an unconditioned ground: 'the proper principle of reason in general ... is to find the unconditioned for conditioned cognitions of the understanding' (A307/B364). But Kant argues that we can never achieve theoretical knowledge of anything unconditioned. ${ }^{5}$ So the faculty of reason demands that we seek knowledge of something of which we cannot achieve knowledge. This means that reason's principle must be restricted to a special status: it is legitimate only as 'regulative' or guiding principle for our theoretical inquiry. But Kant argues that we are naturally tempted to instead accept it as an objective principle guaranteeing that, for anything conditioned, there must really be some complete series of conditions, or some unconditioned ground. ${ }^{6}$ Our temptation to accept this principle, and conclusions drawn from it, is supposed to explain the appeal of rationalist metaphysics. For example, this principle is the ground on which the 'the entire antinomy of pure reason rests': 'If the conditioned is given, then the whole series of all conditions for it is also given' (A497/B525). And this tempting principle is a version of the principle of sufficient reason: for anything that is not a sufficient reason for itself, or for anything conditioned, there must be a complete series of conditions that provides for it a sufficient reason. Kant can explain in these terms, for example, why we are naturally tempted by

\footnotetext{
${ }^{4}$ See Lin 2007 on 'metaphysical rationalism' and Spinoza.

${ }^{5}$ In short, our merely 'discursive' understanding is dependent for all intuition on the faculty of sensibility and the a priori forms of sensibility, space and time (e.g. B135; Prolegomena Ak 4:288); and the forms of space and time prevent theoretical having knowledge of anything unconditioned. E.g. 'In sensibility, i.e. in space and time, every condition to which we can attain in the exposition of given appearances is in turn conditioned' (A508/B536).

${ }^{6} \mathrm{We}$ are subject to 'a natural and unavoidable illusion which itself rests on subjective principles and passes them off as objective' (A298/B354).

Bulletin Of The Hegel Society Of Great Britain
} 


\section{Metaphysics without Pre-Critical Monism: Hegel on Lower-Level Natural Kinds and the Structure of Reality}

rationalist arguments from the existence of anything conditioned to the existence of God as an ultimate ground or an original being. ${ }^{7}$ But he can also argue that such rationalist arguments must be rejected: to assert knowledge of the principle grounding such arguments, or of such conclusions, is to violate our epistemic limits — for these limits prevent all knowledge of anything unconditioned.

Now when it comes to Hegel, one can certainly propose that he assumes the basic premises of metaphysical rationalism, and argues for a modified version of that kind of view. But one should then accept that this is to beg the question against Kant - it is to meet with mere assumptions Kant's arguments against rationalism. We must not let Hegel off too easily on this score. We should not say that Kant's criticisms of rationalist metaphysics target specifically the idea that that there is a transcendent or otherworldly God, separate from the world; nor should we say that Hegel escapes Kant's criticisms of rationalism insofar as Hegel follows Spinoza in rejecting such a transcendent God. ${ }^{8}$ For metaphysical rationalism need not have anything to do with anything otherworldly. Kant himself says that one way to think about the 'unconditioned' is to think of it as 'the whole series, in which thus every member without exception is conditioned' (A417/B445). And one could hold that everything real is part of just such a series, so that everything real has an unconditioned ground in the whole or totality of reality. This kind of monism would be a form of metaphysical rationalism; I will call it 'rationalist monism.' Interpretation of Spinoza is beyond my scope here, but it is worth noting some affinities with the 'rationalist monism' just defined: Spinoza argues for the existence of God by appealing to the principle of sufficient reason: 'For each thing there must be assigned a cause, or reason, both for its existence and for its nonexistence' (Ethics IP11D); and the God defended by Spinoza is a single substance encompassing everything: 'whatever is, is in God' (Ethics IP15). ' In any case, if Hegel accepts 'rationalist monism,' then he endorses a form of metaphysical rationalism, and he cannot also agree with Kant in rejecting metaphysical rationalism as dogmatic.

I argue that Hegel rejects rationalist monism. And I do not mean that he somehow rejects that view but also accepts it. We can rather explain his position clearly and directly: Hegel entirely rejects all forms of metaphysical rationalism, including rationalist monism. He holds that there is no single ground providing a complete reason

\footnotetext{
7 'If something, no matter what, exists, then it must also be conceded that something exists necessarily. For the contingent exists only under the condition of something else as its cause, and from this the same inference holds further all the way to a cause not existing contingently and therefore necessarily without condition. That is the argument on which reason grounds its progress to the original being' [Urwesen]. Although this argument must be rejected, it is also 'the natural course taken by every human reason' (A584-5/B612-3).

${ }^{8}$ Although I agree with much else in Beiser's metaphysical interpretation, on this particular point I disagree (Beiser 2005: 55).

${ }^{9}$ On the principle of sufficient reason in Spinoza's argument for the existence of God, see Lin 2007. Bulletin Of The Hegel Society Of Great Britain
} 
for everything real, not even in the whole of everything. This is to say that nonmetaphysical interpretations are correct about something important: Hegel rejects a form of metaphysics that Kant was especially concerned to criticise. ${ }^{10}$ But I will argue that all this is compatible with recognition that Hegel's project remains ambitiously metaphysical: Hegel claims to articulate the structure or organisation of reality, and to identify something that is supposed to be most fundamental or 'absolute.'

\section{Levels of Being and the Lower-Level Natural Kinds}

Hegel argues that there are 'levels' of reality, or levels of being. His account of these levels is not supposed to remain neutral on metaphysical issues by being limited to an account of a conceptual scheme or relationships between levels of a conceptual scheme. Hegel argues that reality itself has the structure of a hierarchy of levels. For example, Hegel argues that the natural sciences can discover real natural kinds and laws; the sciences can succeed at 'finding universal determinations, kinds [Gattungen], and laws' (EL $\$ 12 \mathrm{An})$. And at the beginning of the Philosophy of Nature, Hegel characterises the 'levels' of nature as an 'organisation' of 'orders and classes' of 'forces, laws and kinds' (PN \$246). The lecture notes attached to this paragraph emphasise that neither these kinds nor their organisation is just an abstraction of ours: the 'kinds,' Hegel says, 'are not just a grouping of similarities, an abstraction made by us ... they are the objects' own inner essence; the orders not only serve to give us a general view, but form a hierarchy of nature itself.' (PN \$246Zu 9:20/10) ${ }^{11}$

Some will think that Kant's epistemic restrictions should block the possibility of knowledge of such natural laws and kinds. I argue elsewhere (Kreines 2007) that Hegel has arguments to offer in response to such epistemological worries, and that these arguments are compatible with Hegel's agreement with Kant in rejecting metaphysical rationalism as dogmatic. But I focus here on the metaphysical question of whether Hegel's account of the levels of reality amounts to a kind of metaphysical rationalism. I aim to approach this question by considering how the lower levels of nature are supposed to fit into the overall organisation of everything. The lowest level of nature, 'mechanism,' is composed of the single natural kind matter, and the laws governing all matter. ${ }^{12}$ I will focus my attention one level higher. Here we find not a single basic natural kind, like matter, but multiple natural kinds linked by laws. In the 'Observing Reason' section of

${ }^{10}$ So I agree with non-metaphysical readers when they make this point specifically. For example, Hegel 'enthusiastically agreed with Kant that the metaphysics of the 'beyond,' of substance, and of traditional views of God and infinity were forever discredited' (Pippin 1989: 7) and Hegel's view is 'at variance with the Spinozistic form of holism on which Schelling had drawn' (Redding 1996: 108-109).

${ }^{11}$ On Hegel on the mind-independence of such natural kinds see also Westphal 1989: Ch. 10 and Stern1990.

${ }^{12}$ The 'Mechanism' section in the Logic concludes specifically with discussion of the law of gravity governing the rotation of matter (EL $\S 198 ;$ WL 6:423ff/721ff). 


\section{Metaphysics without Pre-Critical Monism: Hegel on Lower-Level Natural Kinds and the Structure of Reality}

the Phenomenology, Hegel often uses the example of positive electrical charge and the laws governing its reactions with negative charge, and the example of acids, which are disposed to react in various ways with bases. He also discusses this topic in the Logic, labeling this broad level of nature 'Chemism,' while noting that the topic of such natural kinds linked by laws is broader than just the specific subject area of the science of chemistry (WL 6:429/727).

Hegel argues that the very nature of such a natural kind will depend on its relations to others. What it is to be acidic, for example, depends on how acids react with bases. There is no part of the answer to the question 'what is it to be acidic?' that is independent of the laws governing its relations with other kinds. In Hegel's terms, the general point is that 'the chemical object is not comprehensible from itself alone, and the being of one is the being of the other' (WL 6:430/728). And this will mean that the 'being' of such a kind will depend on the whole interconnected network of kinds and laws within which it is a part. In Hegel's terms, on this level of nature the 'determinateness' of anything in particular 'is the concrete moment of the individual concept [Begriff] of the whole, which Begriff is the universal essence, the real kind [Gattung] of the particular object' (WL 6:430/728).

Note that Hegel's point here has not been rendered outdated by progress in the natural sciences. True, we can today explain the natures of different chemical kinds in terms of their underlying chemical structure. But this scientific progress only shifts the domain to which Hegel's point would apply; it does not settle the question of whether the basic point is correct. For chemical structure will have to be a structure of something. Say for the moment that it is at the basic level the structure of electrons, protons and neutrons. The question will now be, what is an electron? One answer will be that an electron is fundamentally something that interacts in certain law governed ways with other electrons and other basic particles. To accept that answer is to accept Hegel's philosophical point about the lower-level natural kinds and laws. Whatever natural kinds turn out to be most basic, so long as there are diverse kinds connected by laws, we can consider whether Hegel's philosophical point would apply there. Some philosophers recently have argued that it must. Consider Blackburn:

Just as the molecular theory gives us only things with dispositions, any conceivable improvement in science will give us only a better pattern of dispositions and powers. That's the way physics works. Is it the way it has to work? I believe so. A quick route to this conclusion is to see the theoretical terms of a science as defined functionally, in terms of their place in a network of laws. (Blackburn 1990: 63) 
This is to say that Hegel's philosophical conclusion is correct of the objects of physics, and must be.

But contemporary philosophers generally take this conclusion to raise a problem. In Armstrong's terms, the objects of physics:

[S]how a distressing tendency to dissolve into relations that one object has to another. What, then, are the things that have these relations to each other? Must they not have a non-relational nature if they are to sustain relations? (Armstrong 1993: 282)

Chalmers similarly worries that the resulting view of physical reality as entirely relational would be 'a strangely insubstantial view of the physical world' (Chalmers 1996: 153-154). Bertrand Russell insists that physical reality cannot be so:

There are many possible ways of turning some things hitherto regarded as 'real' into mere laws concerning the other things. Obviously there must be a limit to this process, or else all the things in the world will merely be each other's washing (Russell 1954: 325)

Some, including Russell and Chalmers, take seriously the possibility that this worry might motivate a form of panpsychism, or a similar view: the view that physical reality has an inner side, as it were, that is at least akin to the mental or phenomenal - that 'the intrinsic properties of the physical are themselves a variety of phenomenal property' (as Chalmers reads Russell) or 'proto-phenomenal properties' (as Chalmers suggests). ${ }^{13}$

Consideration of the contemporary worry about the strangely insubstantial view of nature can help us to place Hegel's view more precisely. One possibility is that Hegel agrees with Russell that there must be something real over and above things that are each other's washing, something independent of its relations to other things. Of course, we have just seen that Hegel denies that individual lower-level natural kinds can be this independent something. But that leaves open the possibility that Hegel finds the independent something in the whole network of laws and kinds. The view would be this: physical reality consists of basic natural kinds. What it is to be one such kind would be to be disposed to react in certain ways with others. But the whole network would have an intrinsic nature, and understanding this nature would provide an explanation of why there are such kinds, and why they are interrelated as they are. So the whole would have a nature that itself determines or provides a reason for all of the parts and the relationships between them. On such a view, physical reality would not be 'strangely insubstantial,' in

${ }^{13}$ Chalmers 1996: 153-154.

Bulletin Of The Hegel Society Of Great Britain 


\section{Metaphysics without Pre-Critical Monism: Hegel on Lower-Level Natural Kinds and the Structure of Reality}

Chalmers's terms; what would be strange would rather be that all of the substantiality is found only in the whole of physical reality.

But this sort of monism is precisely what we do not find in Hegel's account of this level of nature. Hegel is rather arguing that this level of physical reality is 'strangely insubstantial.' There is something missing on this level of nature — it is marked by a lack of anything independently substantial. For example, 'Observing Reason' says of the relation between acids and bases, that 'they are only this relation' (Phän 3:195/153). And what is crucial is that even the whole network, on this lower level of nature, is nothing over and above the relations of its parts; not even the whole has an independently substantial nature that determines why there are distinct parts or nodes, and why they are linked in the way that they are. The whole rather merely presupposes the differences between and relations among natural kinds. In the terms from the Logic, chemism 'has as its presupposition, not just the differentiated nature of the objects, but also their immediate independence' (EL S202). Similarly, if grasping the whole were to reveal a reason for or explanation of why the different kinds are related as they are, then this would be to reveal an intrinsic or internal connection between kinds; but Hegel says that, on this level of nature, 'these forms still remain external to each other' (EL\$202). The differentiation of separate kinds is immediate, or has no mediating ground or determination - not in the whole or anywhere else: 'chemism' is 'still infected with the immediate self-subsistence of the object and with externality' (WL 6:434/731). Finally, it is not the case that this whole itself determines the differentiation of and relationships between its parts - the whole or totality of kinds and laws is 'not yet' what Hegel calls a 'totality of self-determination' (WL 6:434/731-2).

So on this level of nature everything is strangely insubstantial. Hegel does not deny but rather highlights the strangeness. In 'Observing Reason' in the Phenomenology, Hegel expresses the point in this way: we can observe an instance of some physical kind - some acid, for example — and it certainly seems independently substantial. But when we seek to understand what it is we are observing, we find something confusing: it 'gets lost' in its relations with others, or dissolved into chains of dependence; it 'becomes something else than it is empirically, confuses cognition' (Phän 3:190/149). Note the similarity to recently prominent discussions: in Armstrong's terms, for example, such things 'show a distressing tendency to dissolve into relations' (Armstrong 1993: 282). Hegel's claim here is not that we find something substantial in the whole; rather something — independent substantiality — goes missing entirely. In fact, Hegel refers to this result as a kind of 'contradiction' inherent in this level of reality: everything here is dependent; and yet we cannot understand how anything here could be dependent because there is nothing here independent enough that anything could depend upon it. Alternatively: the various natural kinds are merely dependent on one another within a whole network; but this 'confuses cognition' insofar as nothing, not even the whole 
network, can provide the sort of independent support upon which something might depend. Or, finally, the parts depend on one another within a whole network, so that the concept or 'Begriff of the whole' is 'the real kind of the particular object'; but this is confusing insofar as the whole itself merely presupposes the differentiated kinds, or depends on their differentiation as a kind of posit: 'the chemical object ... is thus the contradiction of its immediate positedness and its immanent individual concept' (WL $4: 430 / 728)$.

\section{A Brief Look at the Higher Levels: Biology and Spirit}

My focus here is Hegel's account of the lower level of physical reality discussed above. But in order to consider how this level fits into the larger hierarchy, I need to consider as well the higher levels. What is really important here is that each higher level is supposed to diminish the lack or absence of independent substantiality that characterises the lower levels of nature. Now it might be difficult to see what this could mean. Or perhaps it seems unintelligible. To answer such worries, I will very briefly sketch an interpretation of Hegel's account of the higher levels. But there can be no question of defending the details of my interpretation of all this. What is crucial is to develop some terms in which to discuss the higher levels, so as to then return to consider in a determinate manner how these relate to the lower levels.

Consider first Hegel's account of the biological level of nature. Of course, Hegel is wrong wherever his claims contradict later scientific insights, such as those in evolutionary biology. But I have argued elsewhere (Kreines 2008) that Hegel's philosophical argument in defense of teleological explanation in biology is entirely independent of any such obsolete scientific claims. More specifically, Hegel argues that living beings are composed of material parts themselves explicable in lower-level terms - for example, in terms of the natural laws and kinds noted above; and Hegel provides philosophical arguments for the conclusion that living beings themselves are not explicable in lower-level terms, but rather in teleological terms.

Here what is important is the way in which this claim about teleology relates to the lack of substantiality discussed above. Recent philosophers tend to worry about the idea that physical reality might lack purely non-relational properties to support its relational properties. But Blackburn) points out that it is hard to even conceive of how there could be such support: to say that $\mathrm{X}$ is an underlying non-relational property that supports relational properties would be to characterise $\mathrm{X}$ in relational terms - in terms of its grounding or supporting something else (Blackburn 1990:64). In any case, Hegel conceives of the lack of substantiality differently: he conceives of it as a lack of any independent source of activity. So he is especially interested in the sense in which a living organism does not depend on something else outside of it to determine its nature; its nature is fixed by the way that it itself employs the different parts of its body in actively 


\section{Metaphysics without Pre-Critical Monism: Hegel on Lower-Level Natural Kinds and the Structure of Reality}

seeking survival. In 'Observing Reason,' Hegel says that 'the distinguishing marks of animals, e.g., are taken from their claws and teeth ... each animal itself separates itself from others thereby' (Phän 3:190/149). The idea is that determinate features such as claws and teeth, used in determinate ways, fix the nature of a biological species. ${ }^{14}$ For example, part of what distinguishes a species of tiger is the specific way in which it uses its claws to climb the trees present in its environment, to hunt prey present in its environment, etc. Compare this relation between animal and environment to Hegel's account of acids and bases. In the latter case we are supposed to get lost in chains of dependence: If we ask why an acid behaves in a certain way in the presence of something basic, we find that it is the nature of an acid to react with a base in this way. We might seek further explanation by considering the nature of a base, but we are then led back to acids: we find that it is the nature of something basic to react with acids in this way. Of course, current physics can pursue the matter further, but the idea is that we still come to a point at which we get lost in such chains of dependence. But matters are different with the tiger and its environment. If we ask why the tiger has certain features, then - although we will find some limitations here as well - there is at least an answer that can make more progress toward explanation by referring to this very kind of thing itself: it has those features on account of their contribution to an end intrinsic to the tiger, namely, self-preservation. For example, Hegel says, 'in this way the living thing is articulated purposefully; all its members serve only as means to the one end of self-preservation' (VPA 13:193/1:145). ${ }^{15}$ So the intrinsic end is supposed to allow the nature of a biological species-kind to be manifest in the determinate way that it relates to the environment, yet without its nature being merely dependent on such relations. In 'Observing Reason' Hegel says, for example, that the organism is 'the real end or Zweck itself ... it preserves itself in the relation to an other' (Phän 3:198/156).

As noted above, Hegel takes the natural sciences generally to seek knowledge of 'universal determinations, kinds [Gattungen], and laws' (EL \$12An). But now we can appreciate his reasons for claiming that there is a philosophically significant difference between two different orders or classes of natural kinds or Gattungen: lower level natural kinds connected by laws lack the independent substantiality of higher level biological species-kinds. This is the sort of difference in virtue of which Hegel concludes that there are distinct levels of natural kinds, so that nature itself has an organisation or structure.

\footnotetext{
${ }^{14}$ I generally translate Hegel's Gattung, used in biological contexts, as 'species' or 'kind' rather than 'genus'. One case in which this is clearly the best translation is this: a living individual 'reproduces itself as another individual of the same species or kind [Gattung]' (PP 4:32/142). And 'species' is the best translation where Hegel refers to the propagation of the 'species' or 'die Fortpflanzung der Gattung' (PN §365Zu p. 404/492).

${ }^{15}$ The end is preservation of the individual and of the species: 'the end of the animal in itself as an individual is its own self-preservation; but its true end in itself is the species' (VGP 20:87/3:185). See also $E L \S 221$ and $W L$ 6:484/773-4.
} 
Hegel is also interested in biology because he finds here, for the first time, an explanation of the interdependence of the whole and of the parts. Reproduction by individuals explains how the general kind [Gattung] is realised and effective in the world; and the general kind reciprocally explains the development and capacities of each new concrete individual. Here concrete and the universal are supposed to be two sides of one system, which Hegel calls 'concrete universality. ${ }^{.16}$

But it is crucial that Hegel will also find a limitation on this biological level. A biological species-kind has, at a fixed point in time, the sort of independent substantiality noted above. But a biological kind itself is shaped over time by its environment. Hegel says, in the course of praising Cuvier: 'nature shapes and adapts this organism to the particular element in which it is placed, to climate, to a particular form of food, in general, to the environment' (PN \$368An). Hegel adds that the biological species-kinds are shaped by contingent changes in the environment: 'the kinds [Gattungen] are completely subject to the changes of the external, universal life of nature, the vicissitudes of which are shared by the life of the animal' ( $P N \$ 368 \mathrm{An})$. This is supposed to make biological life, although it is the highest level of nature, similar to lower levels in that it lacks anything whose nature is completely determined in an independent manner. Alternatively, things on this level of nature are also dependent for their nature on their relations over time with other merely external parts of the natural environment and biological life generally.

Although biology is supposed to be the highest level of nature, there is supposed to be an additional highest level of being, the level of Geist or 'spirit.' Spirit is something akin to a biological species-kind or Gattung, and so a kind of concrete universal. This is to say that spirit and its distinction from nature has nothing to do with immaterial substance. Individual geistig beings are composed of matter, like all living beings. Geistig beings are distinguished by the capacities for thought and self-consciousness. And these capacities are supposed to ground yet another philosophically significant distinction between classes of kinds - they are supposed to make the general kind Geist different than a biological species or lower-level natural kinds.

More specifically, these capacities are supposed to make Geist change over time in a unique manner. First, Hegel will argue that spirit develops or changes over time, through different shapes or structures, even where there is no change in the natural environment and no change in the biological structure of individuals. An example of such a change, from the Phenomenology, would be the breakdown of ancient Greek ethical life, which Hegel approaches by considering Sophocles' Antigone.

Second, the point is not just that spirit is independent of nature in its development; spirit is supposed to develop in a manner that depends on itself. For

16 See Hegel's connection between the concrete universal and Kant's analysis of inner purposiveness (WL 6:443/739). On this issue and the connection to issues concerning logic, see especially Thompson 1995.

Bulletin Of The Hegel Society Of Great Britain 


\section{Metaphysics without Pre-Critical Monism: Hegel on Lower-Level Natural Kinds and the Structure of Reality}

example, Hegel will argue that thinking and self-conscious beings cannot sustain a form of life in which questions are answered and conflicts resolved by appeal to tradition or to nature. Such beings will inevitably come into conflict over questions of who or what they are, and over what they should do and should become. Further, such beings will be increasingly aware that they are shaped by such internal conflicts, more than by any external factors, such as the natural environment. So, over time, such beings will be less able to resolve conflicts, and less interested in resolving conflicts, by appealing to a supposedly given or fixed nature of things, or to tradition; they are supposed to inevitably tend, over the very long haul, toward developing ways of legitimately resolving conflicts and reconciling that are independent of such external appeal. In terms of the Phenomenology, spirit develops toward mutual recognition, or toward what Hegel calls 'a reciprocal recognition which is absolute spirit' (Phän 3:493/408). Here I would follow Pinkard: the idea is that historically developing self-conscious beings will inevitably come to face the problem of 'groundlessness' and to embrace the project of 'self-grounding' (Pinkard 1994: 269).

And third, these claims about our historical development are supposed to be independent of our biological nature. They would remain true if we were composed of different elements, for example. Granted, Hegel's spirit is not unconditioned in Kant's sense. For the existence of spirit depends on the existence of nature; we could not exist without there being a nature in which we are embodied. Hegel's claim, however, is that whatever the natural conditions happen to be does not decisively shape our historical development. ${ }^{17}$ For example, even if thinking and self-conscious beings were made of entirely different natural elements, they would still work their way into conflicts concerning tradition and authority — just as we actually have. Spirit, then, is conditioned, in the sense that its existence depends on the existence of something else; but the nature of spirit is not determined by anything outside itself.

I should note that I borrow heavily here from non-metaphysical interpreters who stress Hegel's claims about the free self-determination of Geist. ${ }^{18}$ But I am arguing that these claims are best understood as part of a metaphysical theory. Granted, part of the point of Hegel's account of spirit is that what we are depends on how we develop over time, and that this depends on our own thoughts and especially our thoughts about what

\footnotetext{
${ }^{17}$ An addition to the Philosophy of Geist considers an example: 'Geist, as embodied, is indeed in a definite place and in a definite time ... the life of man is conditioned ... he could not live at either a greater or a lesser distance from the sun; but the influence of the position of the Earth on mankind does not go beyond that' $(P G \S 392 \mathrm{Zu} /$ 38).

${ }^{18}$ See for example the reference to Pinkard above and the reference to Pippin immediately below. Bulletin Of The Hegel Society Of Great Britain
} 
we ourselves are and should be. ${ }^{19}$ But this is not a claim that is supposed to be limited to an account of how we understand ourselves, or an account of our conceptual scheme, remaining neutral about metaphysical questions. It is a metaphysical account of what we ourselves really are, and how we relate and compare to everything else - it is part of Hegel's broader metaphysical account of the broader structure of reality itself, or his larger account of natural kinds and levels of being.

This is all too brief, to be sure. But for my purposes what is crucial is that Geist is in some ways akin to a natural kind or Gattung, and especially to a biological species-kind; but also that Geist is also distinguished from such natural kinds by a kind of free or independent development: Geist is 'free kind [Gattung] coming into existence for itself' (EL \$222).

\section{Hegel Rejects Metaphysical Rationalism, Including Rationalist Monism}

I now return to my central question: how do the lower-levels of nature fit into the overall organisation of all the levels of being? More specifically, do they find a ground or reason in the organisation of the whole? That is to say, are the lower levels as they are specifically because of the way they are to fit into the whole of reality? That is the view that Hegel would have to hold if he were a rationalist monist, holding that everything real must have a complete ground or reason, ultimately provided by the whole. But does he hold it?

We are now in a position to see why this cannot be Hegel's view. The basic reason is this: we saw above that precisely what distinguishes the lower level natural kinds is that they lack any complete reason or ground.

Still, there might seem to be room to propose the following way of reading Hegel as a rationalist monist: Perhaps Hegel holds that objects on the lower-levels of nature receive no complete ground or reason at that level of nature; but (so the story would run) insofar as all lower-level objects are merely dependent, they must ultimately be dependent on some complete ground or reason at a higher level of being.

One might think that this must be Hegel's point. There is something 'distressing' (Armstrong) or 'strangely insubstantial' (Chalmers) about the idea of things which are entirely dependent, without any of them being independent enough for something else ultimately to depend upon it. So we might well think that it would be too strange or distressing to hold that lower-level physical reality is like that. How could Hegel avoid this strange conclusion? Since he locates what is lacking — independent substantiality on the higher levels of being, he would have to do so by concluding that the lower levels

\footnotetext{
${ }^{19}$ I follow Pippin on this point: spirit is 'self-forming in time' in the sense that our 'criteria and values are the way they are because of the determinate insufficiencies of prior attempts at self-understanding and selflegitimation' (Pippin 1991: 68-9).
} 


\section{Metaphysics without Pre-Critical Monism: Hegel on Lower-Level Natural Kinds and the Structure of Reality}

depend on the higher. For example, he might hold that the whole network of lower-level kinds and laws is itself akin to a biological organism. In an organism like a tiger, for example, there is supposed to be an end intrinsic to the whole that explains why it has the parts it does, and how those parts are related - why it has a heart, and lungs, and why these parts are related as they are. Similarly, Hegel might hold that the whole network of natural kinds and laws has an intrinsic end that explains why there are distinct kinds, and why they are related as they are. Or perhaps Hegel holds that the whole network of laws and kinds is somehow akin instead to a thinking and self-conscious being, or to spirit. In any case, it is crucial that such an account would require concluding that lower-level natural kinds only seem to lack a complete ground or reason in a self-determining totality. What is really lacking would be the conception of them as lacking anything independently substantial. The truth would have to be that lower-level natural objects have a hidden side, which reveals them to be grounded in the manner of the parts of a whole that is more akin to a self-determining biological whole, or even a spiritual whole.

But this is precisely what we do not find in Hegel's discussions of the lower levels of nature. Instead of dispelling or filling the lack substantiality at the lower levels of nature with an account of a hidden dependence on higher-level substantiality, Hegel asserts that the lower levels are nature really are strangely insubstantial. Consider again 'Observing Reason.' Here Hegel does not hold that there is something inadequate or incomplete about the conception or image of lower level natural kinds as lacking a complete ground or reason. Rather, Hegel's point is that lower-level natural things are themselves lacking insofar as they really lack a complete ground or reason. For example, looking back at a central passage from above: an animal:

[M]aintains itself for itself and detached from the generality ... What, however stands on a still lower level cannot itself any longer distinguish itself from another, but in being contrasted with it gets lost (Phän 3:190/149).

Lower-level natural objects lose themselves, as it were, in chains of dependence on others; this is to say that they do not find themselves in any termination of those chains. If there is no termination, then there is no termination in a larger whole, nor specifically a hidden higher-level whole. Hegel's point is that lower-level natural objects truly differ from biological phenomena. The point is precisely not that lower-level natural objects have a hidden side that reveals them to parts of a whole that is biological or similar to the biological. Hegel is contrasting the real natures of the inorganic and the organic. For example, after again underlining the dependence of the inorganic, Hegel says that 'in the organic being, on the contrary, every deteminateness through which it is open to an other is controlled by the organic, simply unity' (Phän 3:196/154).

Bulletin Of The Hegel Society Of Great Britain 
Hegel, then, cannot be a metaphysical rationalist of any sort. For he holds that some things lack a complete ground or reason. More specifically, there is no complete reason why any given lower-level natural kind reacts with others as it does, nor any reason why there are diverse lower-level natural kinds, nor any reason why these kinds are arranged as they are in just this network of laws. Further, if Hegel is not a metaphysical rationalist, then he cannot advocate rationalist monism in particular. If some things lack an underlying ground or reason, then it cannot be the case that there is any single ground of everything real — not in the whole of all reality, nor anywhere else.

Similar considerations apply to Hegel's general contrast between nature and Geist. Even the highest sort of natural kind, a biological species, fails to be a self-determining totality. For its nature is shaped by and therefore dependent on the external environment. And to say that it is dependent on something external is to say that there is no underlying ground or reason for why the species and the environment are all arranged as they are. If there were such a ground of these relationships in the whole of nature, then this would establish an internal or intrinsic connection between the different species and their environments. But to say, by contrast, that a species is shaped by something merely external is to say that it is in a sense merely contingent: there is no underlying reason that determines or necessitates the natures and relations between the different species. Hegel says:

In nature, not only is the play of forms a prey to boundless and unchecked contingency, but each separate entity is without the concept of itself. The highest level to which nature attains is life; but this, as only a natural mode of the idea, is at the mercy of the unreason of externality ... whereas in every expression of Geist there is contained the moment of free, universal self-relation. (PN $\$ 248 \mathrm{An})$

In contrasting nature and Geist, Hegel is not saying that there is something limited or incomplete about the image or conception of nature in terms of such contingency and external determination; he is saying that nature and natural things themselves are limited or incomplete insofar as they truly are characterised by externality and contingency in these senses.

Hegel sometimes makes this general point about the limitations of nature itself by referring to a 'powerlessness' or 'weakness' or 'impotence [Ohnmacht] of nature.' This is not to say that there is a weakness in our conceiving nature in terms of contingency and externality; rather, insofar as nature is truly characterised by contingency and externality, and lack of mediation by any complete determining ground or reason, there is in this respect a kind of weakness in nature itself: 
In the sphere of nature contingency and determination from without has its right, and this contingency is at its greatest in the realm of concrete individual forms, which however, as products of nature, are concrete only in an immediate manner ... This is the powerlessness of nature. (PN $\$ 250)^{20}$

Alternatively, nature contains real contingency, in the sense that it contains things that are not necessitated by any underlying ground or reason. For example, take the lower-level natural kinds: no underlying ground or reason necessitates the actual network of kinds; it is merely contingent.

Of course, Hegel does claim that reality as a whole has a structure or organisation. Just not in the sense that everything is as it is in virtue of its place within a whole - not in the sense that the whole provides a complete reason or ground for everything. Rather, reality is organised insofar as it has the structure of a series of levels. And the levels differ precisely insofar as things on different levels either have or lack complete grounds or reasons to different degrees. Similarly, Hegel argues that the whole of everything is similar to a biological organism in the specific respect that both have a structure, or an organisation. But the whole of everything is not organised in the same sense that a living being is supposed to be organised - not in the sense that any purpose or end inherent in the whole explains why its parts are as they are. Rather, the levels of being are distinct insofar as there are many phenomena that differ from the biological in this respect, including the lower-level natural kinds for which there is no further explanation or reason in any larger whole or anywhere else.

In sum, Hegel advocates an ambitious metaphysics, an account of the structure of reality; but it is a metaphysics that involves the rejection of rationalist monism and all forms of metaphysical rationalism.

\section{Objections and Replies Concerning the Absolute and Nature's Dependence}

One obvious objection to my interpretation above is the following: Metaphysical interpretations tend to agree that Hegel's 'absolute' is supposed to be the totality of everything real. ${ }^{21}$ Further, the absolute cannot be something itself merely conditioned or

\footnotetext{
${ }^{20}$ See also PN §250; PN §368Zu 9:510; PN §314Zu.

${ }^{21}$ Beiser thinks that the point raises a problem concerning Hegel's account of contingency. He provides an extremely compelling account of the problem itself, and I agree - although I think that this is not a problem for Hegel but rather a problem for the interpretation of Hegel as a metaphysical rationalist. In any case, Beiser sees this basic point - although it raises a problem — as 'indisputable': 'the absolute is all reality, having nothing outside itself to limit it' or 'make it finite' (Beiser 2005: 76). I would answer that Hegel's absolute is supposed to be infinite in the sense of infinitely self-determining or free. And only Geist is infinite in this sense. In Hegel's terms: 'The infinite is, and more intensely so than the first immediate being ... in the infinite the spirit is Bulletin Of The Hegel Society Of Great Britain
} 
dependent, else it would not be absolute. Nor could the absolute have parts that lack a sufficient ground or reason, else it would not be absolute. And so it seems that Hegel must hold the metaphysical rationalist view that everything real has a complete ground or reason: the absolute.

I would reply, however, that this objection itself provides excellent reason to doubt that Hegel's 'absolute' is supposed to encompass everything. For we have seen that the lack of such complete grounds or reasons is supposed to truly characterise the lower levels of nature. So if the absolute cannot have parts that lack sufficient ground or reason, then the lower levels of nature cannot be part of the absolute. On my account, the concept of the absolute is the concept of something self-determining. Insofar as the lower levels of nature do not satisfy this concept, they are neither absolute nor part of the absolute. Insofar as biological life only incompletely satisfies this concept, it is only an approximation of the absolute. Insofar as the concept of independent self-determination is satisfied completely only by Geist or spirit, it follows that the only thing truly absolute is spirit, or that 'the absolute is spirit — this is the supreme definition of the absolute' ( $P G$ \$384).

The same line of response can be expressed in terms of Hegel's relation to Spinoza. Spinoza defines substance as 'that which is in itself, and is conceived through itself (Ethics 1D3). Hegel argues that the whole of all reality cannot meet Spinoza's definition. For the whole of everything includes lower-level natural phenomena lacking any complete ground or reason anywhere in the whole, so that the whole of everything cannot, in this sense, be conceived entirely through itself. But there is at least one sense in which something meets Spinoza's definition: Geist or spirit does so, at least in a sense. Granted, spirit is conditioned: it requires, for its existence, that there is a nature within which it is embodied. Still, spirit is supposed to be self-determining in a manner that allows its development and the resulting shapes of spirit to be 'conceived through,' or explained by appeal to, spirit itself. So there is one sense in which Geist or spirit is supposed to meet Spinoza's definition. Spirit — not the whole of everything — is the only thing that, in this sense, 'is in itself, and is conceived through itself.' I would argue that this is what Hegel has in mind, in the famous lines from the 'Preface' to the Phenomenology: 'That the true is actual only as system, or that substance is essentially subject, is expressed in the representation of the absolute as spirit' (Phän 3:28/14).

But in my view the most worrying objection is the following: On my account, Hegel holds that lower-level natural objects do not depend on anything at the higher levels - not on anything biological nor on spirit. But there are certainly passages in which Hegel seems to claim that the phenomena of nature are grounded in an inner side

not merely abstractly present to itself, but rises to its own self, to the light of its thinking, of its universality, of its freedom' (WL 5:150/137-8). Again, what is absolute or infinite is specifically Geist. And so Hegel refers to 'that universal which as truly absolute concept is to be grasped as the idea of infinite spirit' (WL 6:494/780).

Bulletin Of The Hegel Society Of Great Britain 


\section{Metaphysics without Pre-Critical Monism: Hegel on Lower-Level Natural Kinds and the Structure of Reality}

that is itself spiritual or akin to some kind of self-consciousness. A striking example, from 'Force and the Understanding' in the Phenomenology, concerns explanation of nature:

The understanding's 'explanation' is primarily only the description of what self-consciousness is ... The reason that 'explaining' affords so much selfsatisfaction is just because in it consciousness is, so to speak, communing directly with itself (Phän 3:133-4/101).

If explaining nature requires describing self-consciousness, then this certainly seems to suggest that nature really depends on self-consciousness or spirit.

Is nature supposed to depend on spirit in some sense? Any good Hegelian would of course like to answer both 'yes' and 'no.' I too would like to give both answers. But I think it crucial to explain philosophically how the answer can be both yes and no - or how a single, coherent and philosophical view could combine those answers. Again, at the end of the day, we need something more to say than just that Hegel's view is dialectical, for that would leave us still in need of an explanation of this terminology and how it pulls off the trick.

I have already argued that, insofar as the question about nature depending on spirit is a metaphysical question, the answer is 'no': lower-level natural kinds and laws do not really depend on spirit or any higher level phenomena; there is no further explanation of why such kinds are as they are, not even an explanation appealing to spirit. But this leaves room for Hegel to answer that nature does depend upon spirit in a sense that is compatible because it is epistemological and not metaphysical. I do not mean by this that the knowability of nature depends on spirit. Rather, the intelligibility of nature - that natural phenomena can be comprehended and explained at all - depends on their place within a whole that includes spirit.

To see the point, consider Kant's account of the faculty of reason. Say we know about something conditioned, $\mathrm{X}$. We are supposed to take an interest in explaining $\mathrm{X}$, specifically by seeking its underlying conditions. We might then discover its underlying condition, $\mathrm{Y}$, where this too is something merely conditioned. Now our interest in explanation cannot simply be satisfied by this discovery. Otherwise we would have already been satisfied to begin with. For knowledge of $\mathrm{Y}$ is precisely like our prior knowledge of $\mathrm{X}$ in the respect that originally left us wanting an explanation: $\mathrm{Y}$ is again something merely conditioned. So our interest in explanation must be an interest in something more than just uncovering underlying conditions. On Kant's account, it is an interest in following the series of conditions to completion, establishing knowledge of something unconditioned. As noted above, Kant rules out the possibility of knowledge of anything unconditioned. But Kant nonetheless argues that we can and must continue to seek to uncover underlying conditions. I take the point to be that we can at least in this 
way make progress in explaining things: insofar as we can follow a series of underlying conditions, we are at least heading in the direction of the ultimate goal - even if we cannot reach the goal. Although Kant's view here is complex, he certainly does argue that the faculty of reason provides the goals guiding our natural scientific inquiry, and that we can only approach these goals 'asymptotically, as it were, i.e., merely by approximation, without ever reaching them' (A663/B691).

Now compare Hegel's accounts of the lower levels of nature. Imagine that we ask why some acid neutralises some base. Here we can discover that the observed substance is an instance of the natural kind acid, and we can discover the law requiring an acid to neutralise a base. But there is an excellent reason to worry that this cannot amount to an explanation. After all, we have only said that this stuff neutralises that stuff because the nature of this stuff is to neutralise that stuff. On the face of it, the explanatory question still stands unanswered insofar as we have nothing more to say about why acids neutralise bases. And yet we can go no farther with such phenomena: on Hegel's account, there is no further ground or reason to be discovered on this level for why there are different natural kinds, and why they are linked as they are by laws. So there is a threat that there is no explanation to be had on this level, or the lower levels of nature. Of course, today the physical sciences can proceed farther here, uncovering the underlying chemical structure. But our progress just brings out how dire the worry is: Our drive for further knowledge is testament to the point that just ceasing with a system of natural laws and kinds does not itself satisfy our interest in explanation. And yet we ourselves cannot ever reach results that are different in the specific respect that leaves our interest in explanation unsatisfied that is the point I borrowed from contemporary accounts above — so long as we must stop somewhere with a system of supposedly basic natural laws and kinds.

I have argued elsewhere (Kreines 2004) that this basic worry about explanation drives Hegel's progress in his account of the lowest level of nature, mechanism. Imagine as a thought experiment the possibility that everything is explicable in lowest-level mechanistic terms and that is all. Hegel argues that there would then be no substance to the notion of explanation itself - the notion of 'explanation', Hegel says, would be a merely 'empty word' (WL 6:413/713-4). So insofar as we take anything to be intelligible or explicable at all, there must be more to reality than just mechanism.

What difference will it make if Hegel is correct that there exists more than just the lower-levels of nature - that there also exists spirit, and that spirit is independently selfdetermining in the sense discussed above? I have said that this changes nothing in Hegel's metaphysics of nature: nature is not spirit, and does not really depend on spirit or anything spiritual or in any sense quasi-spiritual. So what can any of this change about nature and its explanation? The answer is that we can understand nature differently when we view it in context of the whole hierarchy of levels, including spirit. In that context, we can understand the whole network of lower-level natural kinds as related, if only distantly, to the kind of self-determining totality actually found in the case of spirit. For example, in 


\section{Metaphysics without Pre-Critical Monism: Hegel on Lower-Level Natural Kinds and the Structure of Reality}

learning the basic natural kind of something, and the laws connecting that kind to others, we locate things within a broader whole system of laws and kinds. As I have emphasised, this system is 'not yet' the sort of 'totality of self-determination' that might completely satisfy our interest in explanation (WL 6:434/731-2). But the whole network of laws and kinds is at least a distant echo of that kind of self-determining system. And so there is a sense in which we can at least make progress when seeking to explain lower-level natural phenomena: in discovering natural kinds and laws we can explain insofar as we can begin to travel in the direction that would completely satisfy our interest in explanation, if we could go further. Note the differences as compared to Kant's account of our progress in the explanation of nature: First, what prevents us from going further is not, as with Kant, an epistemic limitation - it is rather a limitation of this level itself: on this lower level there is nowhere further to go. Second, on Hegel's account our goal is not knowledge of something completely unconditioned; it is knowledge of something that independently determines its own nature (even if it may be conditioned in the sense of depending on other things for its existence).

One way that Hegel expresses this view of nature is by means of his term 'the idea.' 'The idea' refers to whole systems for which understanding the whole - or 'the concept' [Begriff] of the whole-provides an explanation of how the whole relates to the concrete or objective parts in a manner that is self-determining. 'The idea' is, Hegel says, 'the absolute unity of concept and objectivity' (EL \$213). The biological level provides the first realisation of what Hegel calls 'the idea': 'the idea is firstly life' (WL 6:468/760). But the only complete realisation of the idea is spirit: again, biological life, 'as only a natural mode of the idea, is at the mercy of the unreason of externality ... whereas in every expression of Geist there is contained the moment of free, universal self-relation (PN $\int 248 \mathrm{An}$ ). We can find only very distant echoes of 'the idea' in even the lowest-level of nature. In Hegel's terms, nature is 'the idea in the form of otherness' — nature is different or other than the idea, it is 'external in relation to this idea' (PN \$247). But we can explain nature insofar as what we find there is at least related, if only distantly, to 'the idea.'

The basic epistemological point, then, is this: Imagine that there were only lowerlevel natural kinds - that they exhaust nature and everything. Under those conditions, there would be no sense in which we could make progress in seeking to explain nature. But this is not all that there is, and there is a sense in which we can make such progress. Insofar as we identify natural kinds and governing laws, we take a step toward uncovering the sort of self-determining kind. The idea of such a self-determining kind is not just something we imagine that has nothing to do with reality; nor is it an idea of something of which we could never have knowledge. Rather, Hegel argues that the real world does satisfy just this idea: Geist is real and is such a self-determining kind, and we can find more and less distant approximations of such self-determination elsewhere throughout nature. This is the sense in which explaining nature means finding traces of ourselves 
within it. And that is why Hegel says that the reason "explaining' affords so much selfsatisfaction is just because in it consciousness is, so to speak, communing directly with itself (PhG 3:133-4/101).

\section{Conclusion}

Of course, there can be no question of giving here a comprehensive explanation or decisive defense of an interpretation of all the major points of Hegel's entire theoretical philosophy. What I have argued is that careful attention to what Hegel says about the lower levels of nature, especially in 'Observing Reason' from the Phenomenology, opens the possibility of a surprising approach to Hegel's broader theoretical philosophy — an approach that is surprising in that it can actually incorporate the strongest points from both sides in recent debates about Hegel and metaphysics.

On the one hand, non-metaphysical interpreters are correct to claim that Hegel rejects as dogmatic a form of metaphysics of central concern to Kant: Hegel entirely rejects metaphysical rationalism, including monist forms of metaphysical rationalism. Hegel is not out to revive Spinoza, at least not in the sense of seeking to revive a monist form of metaphysical rationalism. Hegel holds that there is no single ground of all reality - not even in the whole of everything.

On the other hand, none of this requires us to hold that Hegel's project is nonmetaphysical. We can still recognise that Hegel claims to discern the structure or organisation of reality itself. We can even recognise that Hegel provides a metaphysical account of a highest or most fundamental being: not in the sense that there is one ground on which all reality depends, or in which all reality finds a reason or a ground; but there is something, on Hegel's account, that is highest in being completely self-determining namely, spirit. And, on Hegel's account, all other levels of being are more and less distant approximations of this complete self-determination.

And then on yet another hand - hopefully one may appeal to three hands in an interpretation of Hegel - even given all this ambitious metaphysics, we can return and say that non-metaphysical interpreters are correct in another respect: Hegel does hold that nature depends on spirit in an epistemological and not a metaphysical sense. But the point here is not that the knowability of nature depends on spirit. Rather, the intelligibility of nature depends on the reality of self-determining spirit.

In sum, neither side in recent debates need get the short end of the stick, or the short end of the Aufhebung, as it were. There is an approach to Hegel's theoretical 
philosophy according to which the strongest interpretive points on both sides can be preserved, and need not be cancelled. ${ }^{22}$

\section{James Kreines \\ Department of Philosophy \\ Claremont McKenna College \\ jkreines@cmc.edu}

\section{Bibliography}

Armstrong, D. M. (1993), A Materialist Theory of the Mind. Routledge, London.

Beiser, F.C. (1993), 'Introduction: Hegel and the Problem of Metaphysics', in The Cambridge Companion to Hegel. Beiser, F. C. ed. Cambridge: Cambridge University Press.

Beiser, F.C. (2005), Hegel. London: Routledge.

Blackburn, S. (1990), 'Filling in Space', Analysis 50: 62-5.

Brandom, R. (1999), 'Some Pragmatist Themes in Hegel's Idealism', European Journal of Philosophy, 7,164-189.

Chalmers, D. (1996) The Conscious Mind. New York: Oxford UP.

Hartmann, K. (1972), 'Hegel: a Non-metaphysical View', in A. MacIntyre ed., Hegel: A Collection Of Critical Essays. Notre Dame: Notre Dame Press.

Hegel, G.W.F (1995), Lectures on the History of Philosophy. 3 vols. E. S. Haldane and F. H. Simson trans., Lincoln: University of Nebraska Press.

Hegel, G.W.F (1969), Hegel's Science of Logic. A.V. Miller trans., London: George Allen \& Unwin.

Hegel, G.W.F (1970), Hegel's Philosophy of Nature.W. Wallace and A. V. Miller trans., New York: Oxford University Press.

Hegel, G.W.F (1970-1), Werke in zwanzig Bände. E. Moldernhauer und K. Michel eds., Frankfurt: Suhrkamp.

Hegel, G.W.F (1971), Hegel's Philosophy of Mind. W. Wallace and A. V. Miller trans., New York: Oxford University Press.

Hegel, G.W.F (1975), Aesthetics: Lectures on Fine Art. T.M. Knox trans., 3 vols. Oxford: Clarendon Press.

Hegel, G.W.F (1977), Phenomenology of Spirit A..V. Miller tr., Oxford: Oxford University Press.

${ }^{22}$ This paper has benefited greatly from presentation and discussion with participants at the 2007 conference of the Hegel Society of Great Brittan, and from questions from, discussion with and comments by Fred Beiser, Troy Cross, Steve Davis, Michael Della Rocca, Robert Guay, Robert Pippin, Paul Redding, and Bob Stern. 


\section{James Kreines}

Hegel, G.W.F (1986), The Philosophical Propaedentic. M. George \& A. Vincent, eds., A. V. Miller, tr. Oxford, Blackwell.

Hegel, G.W.F (1991), Encyclopaedia Logic. T.F Geraets, H.S Harris, and W.A Suchting trs., Indiana: Hackett Publishing Co.

Horstmann, R. P. (1991), Die Grenzen der Vernunft. Eine Untersuchung zu Zielen und Motiven des Deutschen Idealismus. Frankfurt am Main: Anton Hain.

Horstmann, R. P. (1998/2004), 'Hegel, Georg Wilhelm Friedrich', in E. Craig ed., Routledge Encyclopedia of Philosophy. London: Routledge.

$<$ http://www.rep.routledge.com/article/DC036>

Kant, Immanuel (1998), Critique of Pure Reason. P. Guyer and A. Wood trans., Cambridge: Cambridge University Press.

Kreines, J. (2004), 'Hegel's Critique of Pure Mechanism', European Journal of Philosophy. 12:1: 38-74.

Kreines, J. (2007), 'Between The Bounds of Experience and Divine Intuition: Kant's Epistemic Limits and Hegel's Ambitions', Inquiry 50:3: 306 - 334.

Kreines, J. (2008), 'The Logic of Life: Hegel's Philosophical Defense of Teleological Explanation in Biology' in F. Beiser, ed., The Cambridge Companion to Hegel and NineteenthCentury Philosophy. Cambridge: Cambridge University Press.

Lin, M. 2007. 'Spinoza's Arguments for the Existence of God', Philosophy and Phenomenological Research. 75: 2. 269-297.

Pinkard, T. (1994), Hegel's Phenomenology. Cambridge: Cambridge University Press.

Pippin, R. (1989), Hegel's Idealism. Cambridge: Cambridge University Press.

Pippin, R. (1991), Modernism as a Philosophical Problem: On the Dissatisfactions of European High Culture. Oxford: Blackwell.

Redding, P. (1996), Hegel's Hermeneutics. Ithaca: Cornell University Press.

Russell, B. (1954), The Analysis of Matter. $2^{\text {nd }}$ ed. Dover, New York: Allen \& Unwin.

Spinoza, B. (1994), A Spinoza Reader. E. Curley ed., and trans., Princeton: Princeton University Press.

Stern, R. (1990), Hegel, Kant and the Structure of the Object. London: Routledge.

Taylor, C. (1975), Hegel. Cambridge: Cambridge University Press.

Westphal, K. R. (1989), Hegel's Epistemological Realism. Dordrecht: Kluwer. 